\title{
Terrestrial rabies eliminated in Croatia - a historical overview
}

\author{
Josip Madić ${ }^{1}$, Ljubo Barbić ${ }^{1}$, Ivana Lojkić \\ Department of Microbiology and Infectious Diseases with Clinic, Faculty of Veterinary Medicine, University of Zagreb, \\ Heinzelova 55, 10000 Zagreb, Croatia \\ 2 Department for Virology, Laboratory for Rabies and General Virology, Croatian Veterinary Institute, Savska c. 143, 10000 \\ Zagreb, Croatia
}

OPEN ACCESS

\section{Correspondence:}

Josip Madić

jmadic@vef.hr;

josip.madic@gmail.com

This article was submitted to RAD

CASA - Medical Sciences

as the original article

Conflict of Interest Statement: The authors declare that the research was conducted in the absence of any commercial or financial relationships that could be construed as a potential conflict of interest.

Received: 23 November 2020 Accepted: 4 December 2020 Published: 28 December 2020

Citation:

Madić J, Barbić Lj, Lojkić I. Terrestrial rabies eliminated in Croatia - a historical overview RAD CASA - Medical Sciences. 544=52-53 (2020): 64-76 DOI: https://dx.doi.org/10.21857/

Copyright (C) 2020 Madić J, Barbić Lj, Lojkić I. This is an open-access article distributed under the terms of the Creative Commons Attribution License (CC BY). The use, distribution License (CC BY). The use, distribution
or reproduction in other forums is permitted, provided the original author(s) and the copyright owners(s) are credited and that the original publication in this journal is cited, in accordance whit accepted adacemic practice. No

use, distribution or reproduction is permitted which does not comply with

\begin{abstract}
:
Rabies is an ancient disease, known worldwide for a thousand years. Nowadays, vast areas of Western and Central Europe have been freed from rabies. To mark the expectation that Croatia will be officially declared free of classical terrestrial rabies by 2020 , this paper was written to present a historical overview of the epidemiological characteristics of rabies in Croatia, based on literature data. Rabies in humans and animals was described in the $19^{\text {th }}$ century on the Croatian territory as a significant public health problem. It caused considerable human and animal death. One of the oldest report of rabies in Croatia is dated in 1783, when two people from the city of Šibenik were bitten by a rabid cat and a rabid dog. Epidemics of rabies that were spread by packs of stray dogs prompted the state authorities in the second half of the $19^{\text {th }}$ century to control the movements of these dogs. The first announcement of taxes on dogs in Croatia was recorded in 1857. However, it was introduced as early as January $1^{\text {st }}, 1867$. The first campaign of preventive dog vaccination by a phenol vaccine prepared from virus fixé, was performed in 1933. Dog vaccination and strict control measures resulted in the reduction of dog-mediated rabies cases to zero in the whole of Croatia in 1967. Ten years later, the first cases of sylvatic rabies in Croatia were detected in three foxes. By the end of 1986 rabies was found in the whole territory of Croatia apart from Dubrovnik and the islands. Introduction of oral vaccination of foxes throughout the whole Croatian territory in 2011, resulted in the rapid decrease of rabies cases in animals to zero in 2014. Recent studies have been focused on rabies in bats. Neutralizing antibodies against the European bat lyssavirus-1 were detected in bats which proves that the bat population in Croatia was in contact with the virus.
\end{abstract}

\section{KEYWORDS: rabies, Croatia, animals, history}

\section{SAŽETAK:}

Bjesnoća je od davnina poznata i proširena diljem svijeta. U novije doba zemlje zapadne i središnje Europe slobodne su od bjesnoće. Očekuje se da će 2020. godine i Hrvatska biti proglašena slobodnom od klasične (zemaljske) bjesnoće pa je taj događaj bio poticaj za pisanje ovog preglednog članka, koji je napisan sa svrhom da se pruži opširan prikaz zapisa, znanstvenih i stručnih članaka objavljenih o bjesnoći u Hrvatskoj. Bjesnoća je u 19. stoljeću predstavljala značajan javnozdravstveni problem. Bila je čest uzrok neizbježne smrti čovjeka i uginuća životinja. Jedan od najstarijih opisa bjesnoće u ljudi ugriženih od bijesnog psa i bijesne mačke na području grada Šibenika objavljen je 1783. Epizootije bjesnoće među psima lutalicama prinudile su državne vlasti u drugoj polovici 19. stoljeća da donesu kontrolne mjere o kretanju takvih pasa. Godine 1857. najavljeno je uvođenje poreza na pse. Uz odredbe o nošenju pasjih markica taj je porez uveden tek 1867. Prvo opširno cijepljenje pasa fenolnim cjepivom pripravljenim od "virusa fixe" provedeno je 1933. godine. Cijepljenje i stroge kontrolne mjere dovele su postupno da smanjenja broja bijesnih pasa i do iskorjenjivanja urbane bjesnoće 1967. these terms. 
godine. Deset godina kasnije u Hrvatskoj su se u lisica pojavili prvi slučajevi silvatične bjesnoće. Do 1986. silvatična bjesnoća zahvatila je sve krajeve Hrvatske osim dubrovačkog područja i otoka. Sustavno oralno cijepljenje lisica protiv bjesnoće započelo je 2011. godine, a posljednji slučaj bjesnoće u lisica zabilježen je 2014. godine. Nova istraživanja usredotočena su na bjesnoću u šišmiša, a publikacija iz 2018. godine iznosi da su neutralizacijska protutijela dokazana u šišmiša iz hrvatskih špilja.

KLJUČNE RIJEČI: bjesnoća, Hrvatska, životinje, povijest

\section{INTRODUCTION}

Rabies (lyssa, hydrophobia) is a fatal viral zoonosis caused by viruses belonging to the genus Lyssavirus, family Rhabdoviridae infecting all warm-blooded mammals. The disease is a major public health threat. More than $99 \%$ of human rabies cases occur in developing countries. The World Health Organization (WHO) reported that around 59,000 human deaths occur annually around the world due to dog-transmitted rabies. Human cases are prevented by prompt administration of post-exposure prophylaxes. However, control and elimination of rabies worldwide is only feasible by vaccination of reservoir populations, dogs and foxes. A country can be declared free of dog rabies if indigenously acquired dog-mediated rabies cases have not been confirmed in humans, dogs or any other animal species for at least 2 years.

WHO, the Food and Agriculture Organization of the United Nations (FAO), and the World Organization for Animal Health (OIE) launched a new United Against Rabies Forum, aimed at accelerating worldwide progress towards the elimination of human deaths from dog-mediated rabies by 2030. It is emphasized that rabies is still killing one person every nine minutes, and almost half of them are children. ${ }^{2}$

Three facts prompted us to present this short historical perspective of rabies in Croatia. (1) The European Union (EU) announced major vaccination programmes for rabies eradication in wildlife. The goal was to eliminate wildlife rabies from the EU by 2020 . It was emphasized that a major effort is still needed, particularly in areas close to the eastern borders of the EU. All Member States have applied rabies surveillance systems, oral rabies vaccination of foxes (ORV) by aerial bait distribution, monitoring of bait distribution, and fox population immunity. The reduction of reported wildlife rabies cases is the most important proof that rabies elimination from Europe is progressing. ${ }^{3}$ (2) The Institute Pasteur (along with its local Department in Velika Gorica) was set up in Croatia in Zagreb 102 years ago, i.e. in 1918, after the collapse of the Austro-Hungarian Empire. As in other countries, its role is to administer vaccines for rabies and antirabies protection. Before its establishment, all people exposed to rabies virus had to travel to Budapest or Vienna for post-exposure treatment (PET) rabies prophylaxis. The first post-exposure treatment of a patient bitten by a rabid dog in Croatia took place in Zagreb on $26^{\text {th }}$ of December 1918.4,5,6 (3) The last positive animal case of rabies in Croatia was recorded in a fox in February 2014, however, a comprehensive description of the efforts taken to eliminate rabies in Croatia by oral rabies vaccination of foxes was published in 2018, a 100 years after the first PET in Croatia. ${ }^{7}$ Moreover, it was announced that the next step for Croatia is obtaining the official status of a rabies-free country. ${ }^{8}$

\section{LYSSAVIRUSES}

Currently, 17 species are assigned to the genus Lyssavirus. Lyssaviruses are distributed worldwide, except in Antarctica and some isolated islands. ${ }^{9}$ The classical rabies virus (RABV) is the archeotype of the genus Lyssavirus. Bats (order Chiroptera) have been recognized as the principal reservoir hosts for 15 species of lyssaviruses. Among them, the Mokola and Ikoma lyssaviruses have not been reported in bats. ${ }^{1}$ Mokola has often been isolated from rodent species, however Ikoma has only been isolated from a rabid African civet (Civettictis civetta). ${ }^{10}$ Bat transmitted human rabies is rare but not negligible. However, in countries where terrestrial rabies has been eliminated, bat rabies remains a constant threat, as shown by human cases of bat rabies in North America. ${ }^{11}$

All lyssaviruses cause acute progressive encephalitis in mammals, being transmitted by infected saliva directly through bites, scratches or mucous membranes. As a neurotropic pathogen, delivered into a wound by a bite or wound contamination, the lyssavirus can replicate at the inoculation site in skeletal muscle cells. ${ }^{12}$ After reaching the motor or sensory neurons, the virus propagates up to the central nervous system (CNS) via neuronal connections and retrograde axonal transport. From the CNS, the virus disseminates rapidly. Soon all regions of the CNS may be affected. The asymptomatic incubation period varies (two months on average), however the symptomatic clinical period is rapid and severe (about one week). ${ }^{13}$

\section{CANINE RABIES}

In the past centuries, rabies occurred predominantly in dogs. Canine rabies is still widespread, occurring in over 100 countries and territories, predominantly in the developing world. More 
than $95 \%$ of human rabies cases are transmitted by dogs. Therefore the control and elimination of rabies in dogs is essential for the prevention of rabies in human beings. Dog-mediated rabies has been eliminated in North America, western and central Europe, Canada, Japan, and parts of Asia and South America. Turkey is the only country in Europe where urban dog-mediated rabies persists.

Effective intersectoral cooperation within a "one health" approach, including animal and public health and mass parenteral canine vaccination, are the key to dog-mediated rabies control. ${ }^{1}$ Annual canine vaccination coverage of at least $70 \%$ is considered sufficient to maintain the required level of herd immunity in the susceptible population, and to ensure control and eventual elimination of rabies. ${ }^{14}$

\section{WILDLIFE RESERVOIRS OF RABIES}

Species of the orders Carnivora and Chiroptera are recognized as wildlife reservoirs of rabies. The epizootic of rabies that broke out in eastern Europe in 1939 was maintained by red fox (Vulpes vulpes) and racoon dogs (Nyctereutes procyonoides). This sylvatic rabies epizootic spread from Poland to Germany in 1940 and further to France in 1968 and Italy in 1980. It spread to the South at approximately $25-60 \mathrm{~km}$ per year. ${ }^{15}$ This wave reached Hungary in 1972 and Croatia in 1977..$^{16,17}$ To control sylvatic rabies, oral rabies vaccination (ORV) of foxes with bait delivery systems proved to be a successful tool, and a prime example of a new strategy to eliminate disease from wildlife reservoirs. ${ }^{18,19}$ The first ORV field trial was conducted in Switzerland ${ }^{20}$ and was followed by other European countries. It led to the elimination of fox-mediated rabies from northern, western and central European countries. ${ }^{1}$ Once brought under control, additional campaigns are needed to eliminate rabies, and vaccination should be maintained for a period to ensure freedom from the disease. ${ }^{19}$ Thanks to oral rabies vaccination programmes over the past three decades, Western and Central European countries have been freed from rabies, and the disease is expected to be eliminated from animal sources in the near future. ${ }^{21}$

In the African continent, the domestic dog is the primary host. However, some rare African canids, such as the Ethiopian wolf (C. simensis) and African wild dogs (Lycaon pictus) are suspected of transmission of the rabies virus. In Southern Africa, jackals (Canis adustus and C. mesomelas) transmit the virus. Bat-eared foxes (Otocyon megalotis) and the mongoose (Herpestidae) are also sustained sources of rabies virus in Africa. In Namibia, the kudu (Tragelaphus strepsiceros) is suspected of direct oral transmission. ${ }^{1}$ The red fox ( $V$. vulpes) is a primary source of the virus in continental Asia. In Russia, northern China and Korea, raccoon dogs (Nyctereutes procyonoides), and in Southern China and Taiwan ferret badgers (Melogale moschata) are reservoirs of the rabies virus. The red fox ( $V$. vulpes) has been shown to sustain rabies in Israel, the West Bank, the Gaza Strip. In the Islamic Republic of Iran, Oman, Saudi Arabia and Yemen, the red fox ( $V$. vulpes) and the golden jackal ( $C$. aureus) are reported to be hosts of the rabies virus. In other countries in the Middle East and Asia, the red fox ( $V$. vulpes), in North America the red fox ( $V$. vulpes), the grey fox (Urocyon cinereoargenteus) and coyote (Canis latrans), on the Eastern Canadian border and the USA the primary host is the raccoon (Procyon lotor). In polar regions, the Arctic fox ( $V$. lagopus) is the primary host, in California the striped skunk (Mephitis mephitis), in Mexico the skunk (Spilogale spp.) and coati (Nasua nasua), in South America the marmoset (Callithrix jacchus), the crab-eating fox (Cerdocyon thous), Kinkajou (Potus flavus) and coati (Nasua nasua). Finally, on Caribbean islands, including Cuba, the Dominican Republic, Grenada, Haiti and Puerto Rico, the Indian mongoose (Herpestes auropunctatus) is the primary host.

\section{DOG-MEDIATED RABIES}

The most detailed historical data and analyses of rabies in Croatia, recorded in books, brochures, circulars, regulations, and the press from the $18^{\text {th }}$ and $19^{\text {th }}$ centuries, with particular reference to their notions of the etiology, diagnosis, prevention, and treatment of rabies, have been published by Karlović and Sudnik. When comparing their data with contemporary knowledge about rabies, we find a great many false beliefs described. Most of them actually give the opinions existing at that time in the neighbouring countries. ${ }^{22}$

According to Karlović et al. ${ }^{23}$, the oldest description of rabies, in two people from the city of Šibenik, bitten by a rabid cat and a rabid dog, was reported in $1783 .{ }^{24}$ Rabies in humans and animals in Croatia within the Austro-Hungarian Empire was often described in the $19^{\text {th }}$ century as a significant public health problem. In the middle of the $19^{\text {th }}$ century, several doctoral theses on human rabies were published. ${ }^{23}$ Karlović et al. also wrote about the first report of rabies cases in dogs in 1822. In addition to the clinical picture, measures for control and reduction of the number of rabid animals (killing and burying killed and dead dogs) were also recorded. ${ }^{25}$ In a document printed in the city of Osijek in 1823, which is actually a pronouncement describing the signs of dog rabies and the rules for handling the carcass of a rabid animal, a drawing of a dog with paralytic rabies is given. ${ }^{6}$ As reported by Karlović et al..$^{23}$ and Mutinelli et al. ${ }^{6}$, in 1837 the teacher, inventor and medical practitioner, Josip Lalić, was given official permission by the military authorities in Vienna to administer a cure for rabies. He considered that saliva was responsible for the transmission of 'the toxin'. ${ }^{26,27}$ In his doctoral thesis, Čac $(2003)^{28}$ recorded that, in an early report in 1872 , it was stated that dirty water, food shortages, summer heat or bitter cold, fear, excitement and sexual dissatisfaction are causative agents of rabies. ${ }^{29}$

In the past, dog rabies epizootics occurred in many parts of Croatia. An example is the Varaždin County in northern Croatia, 
where ordinary annual epizootics and individual cases of rabies in dogs and humans were recorded in the period from 1895 to 1999. Treatments were reported in tens of postexposure human cases, and the forceful implementation of prophylactic measures, mainly dog vaccination, and the capture and culling of stray dogs described. ${ }^{30}$

Wide-spread epizootics and epidemics of rabies caused by packs of stray dogs in the second half of the $19^{\text {th }}$ century, prompted the state authorities to control the movements of these dogs. The first indication of taxes on dogs in Croatia was recorded in 1857. The tax on dogs and dog tagging were introduced as early as January 1, 1867. After much discussion, two years later, on $1^{\text {st }}$ January 1869 , the order was enforced and all dogs found in the street without a dog tag had to be caught and culled. In the collection of the Archaeological Museum in Zagreb there are 208 dog tags from various Croatian towns and some neighbouring countries. ${ }^{31,32}$ These measures reduced the dog population, but failed to solve the problem. At the beginning of the $20^{\text {th }}$ century legislative regulations were adopted in 1906/07 with the purpose of preventing the risk to human health and pollution of the environment, by taking and delivering material for analysis for rabies to the Bacteriological Institute in Križevci. Examples are given describing inappropriate packing, and the delivery of infectious material. A law was passed during the time of the Kingdom of Croatia and Slavonia. ${ }^{33}$ The rule book on dog keeping in the territory of Savska Banovina, issued in 1938, is an example of how the rules governing dog census, dog keeping, fee payment, tag wearing etc. were explained in detail for dog owners. ${ }^{34}$ From that time, there are more and more reports of animal rabies in Croatia.

After the First World War the rabies situation in the new 'Kingdom of Serbs, Croats and Slovenes' was particularly disturbing because the dog rabies epizootic had spread extensively. ${ }^{6}$ From 1921 to 1925,37 persons were treated at the newly founded Institute Pasteur in Zagreb (36 bitten by dogs, one by a wolf). At first, the Högyes dilution method and the Alivisatos ether vaccine were used, and from 1929 to 1979 , the Hempt vaccine was used. Croatia has not had a case of human rabies since 1964, except two imported cases in 1993, both of which ended in death at the Clinic for Infectious Diseases in Zagreb. ${ }^{6}$
According to Kodrnja, from the Department of Microbiology of the Veterinary Faculty of the University of Zagreb, canine rabies was widespread in Yugoslavia, as well as in Croatia, between the two world wars. He stated that in the whole of Yugoslavia four new cases of rabies appeared in domestic animals per day and one fatal case in humans per week. He proposed a number of preventive measures. The main measure was the preventive vaccination of dogs. ${ }^{35,36,37}$

Since the dog rabies epizootic had spread extensively, the need for a dog vaccination arose. The first preventive dog vaccinations with the phenol vaccine prepared from virus fixé started in 1933. Over a period of three years, laboratory experiments were performed on 1,166 dogs, 3,381 rabbits, 145 sheep, 5 cattle, 9 horses, 4 goats, 153 guinea pigs, 62 rats and mice, 38 cats, 3 pigs and 6 hens. Field trials were performed in five regions: Jastrebarsko, Kostajnica, Donja Stubica, Samobor and Sarajevo. Altogether 3,958 dogs were vaccinated, and 4,550 remain unvaccinated in those regions. In a period of two years before vaccination, 79 rabid dogs were detected, and in a period of two years after the vaccination 24 rabies cases were detected. ${ }^{38}$ In the subsequent field vaccination of dogs in Slavonia in 1940, 22,192 animals were vaccinated with the virus fixé phenol vaccine, type Berlin. In the period of 12 months before vaccination 240 rabid animals were detected. In the same period after vacciantion only 34 rabid dogs were detected. ${ }^{39}$ Unfortunately, during the Second World War the vaccination campaign did not result in a significant reduction of the dog rabies epizootic. The number of stray dogs, wolves and foxes increased during the war. However, after introduction of compulsory vaccination of dogs, the incidence of rabies decreased from 368 cases in animals and 14 humans in 1946 , to 3 cases in animals and none in humans in 1955 . Thus, in 1957 the incidence of rabies was significantly reduced (Table 1). The number of vaccinated dogs increased from 7,929 in 1946 to 139,132 in 1957 . Mostly a vaccine prepared by Hempt's method was used. In 1957, the total number of dogs culled was $20,792 .{ }^{40}$ It should be said that the data about rabies cases in humans presented in Table 2 are not congruent with the number of human cases published by Mutinelli et al. ${ }^{6}$, who reported one case in 1952, and none in 1954. 
Table 1. Cases of rabies in animals and humans in Croatia from 1946 to $1957 .^{40}$

\begin{tabular}{|l|l|l|l|l|l|l|l|l|l|l|l|}
\hline Year & Horses & Cattle & Sheep & Goats & Pigs & Dogs & Cats & Wolfs & Foxes & $\begin{array}{l}\text { In } \\
\text { total }\end{array}$ & Humans \\
\hline 1946 & 11 & 24 & 9 & - & 56 & 235 & 23 & 3 & 7 & 368 & 14 \\
\hline 1947 & 1 & 46 & 4 & - & 54 & 224 & 4 & 4 & 23 & 360 & 17 \\
\hline 1948 & 4 & 15 & 12 & - & 21 & 100 & 15 & 1 & 19 & 187 & 7 \\
\hline 1949 & 1 & 11 & 1 & - & 6 & 26 & 6 & - & 1 & 52 & 1 \\
\hline 1950 & - & 5 & 3 & - & 7 & 30 & 5 & 1 & 3 & 54 & - \\
\hline 1951 & - & 1 & - & - & 5 & 27 & 1 & 1 & 3 & 38 & - \\
\hline 1952 & 1 & 9 & - & 5 & 35 & - & 4 & 1 & 2 & 57 & 2 \\
\hline 1953 & 2 & 8 & 1 & 1 & 5 & 23 & 7 & - & 2 & 49 & - \\
\hline 1954 & 1 & 27 & 1 & - & 1 & 21 & 7 & - & - & 58 & 1 \\
\hline 1955 & - & 1 & - & - & 2 & 13 & 3 & - & - & 19 & - \\
\hline 1956 & - & 5 & - & 1 & - & - & - & - & 1 & 7 & - \\
\hline 1957 & - & 1 & - & - & - & 1 & 1 & - & - & 3 & - \\
\hline
\end{tabular}

Table 2. Cases of rabies in Croatia from 1958 to $1966 .^{41}$

\begin{tabular}{|l|l|l|l|l|l|l|l|l|l|l|}
\hline Year & Horses & Cattle & Sheep & Goats & Pigs & Dogs & Cats & Wolfs & Foxes & $\begin{array}{l}\text { In } \\
\text { total }\end{array}$ \\
\hline 1958 & - & 3 & - & - & - & 5 & - & - & - & - \\
\hline 1959 & - & - & - & - & 3 & 17 & - & - & - & 20 \\
\hline 1960 & - & 2 & - & - & 1 & 6 & 1 & - & - & 10 \\
\hline 1961 & - & - & - & - & 1 & 17 & - & - & - \\
\hline 1962 & 2 & 1 & - & - & 1 & 20 & 1 & - & 18 \\
\hline 1963 & - & - & 1 & - & 1 & 10 & - & - & - & 1 \\
\hline 1964 & - & - & - & - & - & 7 & - & - & - \\
\hline 1965 & - & - & - & - & - & 1 & - & - & 13 \\
\hline 1966 & - & - & - & - & - & 2 & - & - & - \\
\hline
\end{tabular}


About $90 \%$ of the dog population was vaccinated each year in Croatia. Mainly Hempt vaccine was used. This vaccine was prepared as a $10 \%$ emulsion of the brains and spinal cords of horses, donkeys, and sheep infected with virus fixé. The virus was inactivated by $1 \%$ phenol. In 1962 , a field trial with a new live Flury LEP vaccine strain was initiated. By using this vaccine, the complete elimination of urban rabies was acchieved. Simultaneously, strict veterinary sanitary measures were applied, especially the extermination of stray dogs. The last two cases of urban rabies in dogs were detected in Croatia in 1966 (Table 2). The existing control measures resulted in a reduction of rabies cases to zero in the whole of Croatia in 1967..$^{41,42}$ For the next ten years Croatia remained rabies-free until 1977 when an epizootic of sylvatic rabies in foxes occurred.

\section{SYLVATIC RABIES}

Many aspects of dog-mediated, sylvatic rabies and rabies in humans worldwide, from a historical review, through their geographical distribution, etiology, epizootiology, pathogenesis, clinical picture, pathological changes, diagnostic methods, differential diagnosis, economical impact, public health and treatment, to control and prophylaxis, with 497 quoted references, are described in the monograph entitled "Rabies" published by Cvetnić in $1989 .{ }^{43}$ The rabies virus was only occasionally transferred from wildlife and domestic animals to humans. It was spread by the bite of an infected animal containing the virus in the saliva. In all cases of animal bite in an area where rabies had been confirmed or presumed, the wound had to be carefully washed in order to eliminate any potential virus from the wound. Laboratory proof of rabies virus in an animal bite provided indication for immediate post-exposure treatment. The human cases of rabies presented in Table 2 were imported from Bosnia and Herzegovina. ${ }^{43-48}$ Recently, in 2009 a female grey wolf (Canis lupus) attacked a 67- year old man in his backyard in Donji Žirovac in SisačkoMoslavačka County in Croatia. The man suffered from amputation of his left hand, nose, upper lip and a part of the maxilla. He was also severely bitten in his right arm and leg. The isolated virus was closely related to rabies viruses isolated from a dog and reed fox in Italy, a Slovenian isolate, and red fox isolates from the former Federal Republic of Yugoslavia. ${ }^{49}$

The epizootic of sylvatic rabies, which was spreading all over Europe, started before the beginning of the Second World War in the northern regions of Poland. Within the next few years it spread to Czechoslovakia, Austria and the USSR. In 1964 it spread from Germany to Denmark, and thereafter cases were reported in Luxemburg, Belgium and Hungary, and rabies emerged in France in 1968. In 1974 it was recorded in Holland and three years later in 22 out of 32 European countries. In those countries 82,000 animals died from rabies between 1972 and 1976. In 1977 alone, rabies was detected in 13,119 wild animals, 2,600 domestic animals and in 7 human beings. ${ }^{50}$
The first cases of sylvatic rabies were detected in Croatia in three foxes in 1977, in the municipalities of Koprivnica and Daruvar (Miokovićevo), in the central region of Croatia. The first rabid fox was detected in the vicinity of the village of Gola on the border with Hungary. Rabies spread to the east and west, and joined with the cases in Vojvodina and those which had spread from Slovenia. Two years later, in 1979, the first cases were detected in the municipality of Varaždin and in the suburbs of Zagreb. Already in 1981 the first case was detected in the region of Sisak. From 1977 to 1981, rabies was detected in 412 out of 1834 tested foxes $(22.46 \%) .^{23}$ Rabies was confirmed in all municipalities between the Rivers Sava and Drava. In 1982 rabies was detected in foxes in some regions south of the River Sava. It was believed that it had come from Slovenia to Istria and Gorski kotar. ${ }^{51-54}$ By the end of 1986 rabies was present in the whole territory of Croatia except Dubrovnik and the islands. Up to that time rabies had been confirmed in 3093 animals, prevalently in foxes. Altogether 2,875 (92.95\%) rabid foxes were detected. However, dogs and cats were indicated as species with a great impact on rabies transmission to humans (Table 3). ${ }^{52,55,56}$ The red fox is a species very susceptible to the rabies virus. No more than five infective units are enough to infect a fox. On the other hand, the amount of virus excreted by saliva from a rabid fox is very high. One mililiter of the salivary gland can contain more than 30,000 infective units. ${ }^{57}$ 
Table 3. Confirmed cases of rabies in animals in Croatia from 1977 to $1986 .^{52}$

\begin{tabular}{|c|c|c|c|c|c|c|c|c|c|c|c|}
\hline $\begin{array}{l}\text { Animal } \\
\text { species }\end{array}$ & 1977 & 1978 & 1979 & 1980 & 1981 & 1982 & 1983 & 1984 & 1985 & 1986 & $\begin{array}{l}\text { In } \\
\text { total }\end{array}$ \\
\hline Fox & 4 & 26 & 116 & 147 & 186 & 439 & 453 & 726 & 475 & 303 & 2875 \\
\hline Horse & - & - & - & - & - & - & - & 2 & - & - & 2 \\
\hline Donkey & - & - & - & - & - & - & - & 4 & 2 & - & 6 \\
\hline Cattle & - & - & - & - & - & - & 5 & 21 & 10 & 2 & 38 \\
\hline Sheep & - & - & - & - & 1 & 1 & 5 & 15 & 2 & - & 24 \\
\hline Goat & - & - & - & - & - & - & 1 & 3 & - & 2 & 6 \\
\hline Pig & - & - & - & - & - & - & - & 1 & 1 & - & 2 \\
\hline Dog & 3 & 1 & 6 & 2 & 3 & 2 & 6 & 7 & 4 & 3 & 37 \\
\hline Cat & - & 1 & - & 1 & - & 2 & 9 & 13 & 5 & 6 & 37 \\
\hline Deer & - & - & - & - & - & - & - & - & - & 1 & 1 \\
\hline Roe deer & - & - & - & - & - & - & 6 & 10 & 2 & 1 & 19 \\
\hline $\begin{array}{l}\text { Wild } \\
\text { boar }\end{array}$ & - & - & - & - & - & - & - & 1 & 6 & - & 7 \\
\hline Wolf & - & - & - & - & - & - & - & 1 & - & - & 1 \\
\hline Weasel & - & - & - & - & - & - & - & 2 & - & - & 2 \\
\hline Jackal & - & - & - & - & - & - & - & - & - & 1 & 1 \\
\hline Badger & - & - & - & - & - & 3 & 2 & 5 & 5 & 4 & 19 \\
\hline Wildcat & 1 & - & - & - & - & - & 1 & - & - & 1 & 3 \\
\hline Marten & - & - & - & - & - & - & 2 & 3 & 2 & - & 7 \\
\hline Ferret & - & - & - & - & - & - & 2 & - & 1 & - & 3 \\
\hline Rabbit & - & - & - & - & - & - & - & 3 & - & - & 3 \\
\hline In total & 8 & 28 & 122 & 150 & 190 & 447 & 492 & 817 & 515 & 324 & 3093 \\
\hline
\end{tabular}


A high number of rabid cattle and sheep were diagnosed from 1977 to 1986 . Recently, clinical rabies was detected in imported cattle. The clinical signs shown by the diseased animals were characteristic of rabies. ${ }^{58}$

Over the period from 1986 to 1990 in total 12,444 animals were tested for rabies by the immunofluorescence method. Of these, 10,245 were wild animals and 1,199 domestic animals. More than half of all the investigations were performed on foxes - 7,497 (60.2\%). Rabies was diagnosed in 2,006 (26.8\%) of the tested foxes. Among other wild animals, sylvatic rabies was detected in martens (13), badgers (10), does (6), wild cats (2), and one case in a stag, jackal, wild hog, polecat, weasel and hedgehog. In domestic animals, rabies was diagnosed in 37 dogs, 36 cats, 12 sheep, 8 goats, 6 bovines, 6 horses, one donkey and one pig. Rabies spread all over the continental part of Croatia. The region of Dubrovnik was still negative. From 1986 to 1992, rabies was diagnosed in 2,581 foxes and 46 other wild animals. The number of foxes tested was continuously falling, from 1,709 in 1989 to 617 in 1992 . On the contrary, the number of rabid foxes increased. These findings were the consequences of the Homeland War. ${ }^{59-62}$ In the period from 1977 to 2001 at the Croatian Veterinary Institute and regional departments in Križevci, Vinkovci, Rijeka and Split, in total 63,244 animals were tested. Rabies was diagnosed in 10,626 (16.8\%) animals. ${ }^{28,63}$ The first case of a rabid dog in the wave of sylvatic rabies took place in Batina (Beli Manastir) in Slavonia and Baranja in 1977. The dog had bitten his owner. In the next three years, six rabid dogs, two domestic cats and one wild cat were detected. From 1983 onwards, rabies spread over the whole region. A total of 2007 foxes were examined, of which 602 (29.99\%) had rabies. Two persons were bitten by rabid foxes. In relation to domestic animals, most cases were detected in dogs and cats. ${ }^{64}$ During the war, in these territories, 654 animals were examined for rabies from 1991 to 1995 . With 251 cases, rabies was again prevalent in foxes. Compared to the previous period from 1981 to 1990 , there were $67 \%$ fewer foxes examined. ${ }^{65}$

Soon after the emergence of sylvatic rabies in 1977, 4 cases of dog rabies were discovered in the following communities: Beli Manastir, Daruvar, Vinkovci and Županja. From the first cases of sylvatic rabies in 1977 to the end of 2002, in total 7,296 dogs were tested for rabies in Croatia. Rabies was detected in 240 dogs $(3.3 \%)$ in 70 communities from all Croatian counties, except Dubrovnik-Neretva county. None of them had been vaccinated against rabies. Most cases were diagnosed in 1999, with 42 positive findings. ${ }^{28,66}$

A thorough and detailed description of an epizootic of rabies in sheep was given in 2010. That year, there was a marked increase in positive ovine cases compared to all previous years. In total, seven sheep were rabid in a herd. In addition, one asymptomatic cat was euthanized and proved to be positive for rabies. This epizootic was characterized by a high number of rabid sheep, a prolonged clinical course, strong signals on fluorescent antibody tests, and very pronounced histopathological findings. These unusual findings for rabid sheep raised the suspicion of the possibility of a virus strain with lower pathogenicity. ${ }^{67}$ Sylvatic rabies has been described in the Varaždin County. The available data on its occurence stress that the spread started in $1979 .{ }^{52}$ Out of 1665 foxes tested from 1985 to 1995,72 $(4.32 \%)$ were positive for rabies. In the same period, rabies was detected in one cat, one wild cat and one goat. The need was emphasized to cull foxes to lower population density, below the threshold necessary to maintain the disease. Culling methods, such as fox hunting and trapping, were proposed. A systematic reduction in the fox population has proven a significant factor in the control and eradication of sylvatic rabies. It was assumed that oral vaccination of foxes would help to stop the spread of the virus. Calculations relating to the incidence of certain species of wild and domestic animals, the sex and age of animals affected, the season of the year when the illness was most frequent, the ratio of ill animals to the total animal population, the geo-morphological characteristics of the area, all support an enzootic, or an abortive form of a rabies epizootic. Critical evaluation of the risk of contact of humans with animals of various risk statuses, as well as other facts are necessary to make a decision regarding the possible choice of antirabic prophylaxis in persons who are bitten. ${ }^{68-71}$

Over thirty years, in total 57,776 red foxes were tested for the presence of rabies virus and rabies was confirmed in 12,855 specimens $(22.2 \%)$. After the red fox, martens are recorded as the second reservoir of sylvatic rabies in Croatia. ${ }^{28,72}$ Since the epidemiology of rabies in foxes is closely related to their biology and behaviour, a spatially explicit environmental and epidemiological computed model was used to examine the dynamic spread of rabies over the Croatian territory. For that purpose, juveniles, fall migrations, home ranges, population density, litter size, yearly accession, mortality rate, hunting pressure, bite frequency coefficient, and the dominant course of the spread of rabies had to be taken into account. That model showed that rabies spread from east to west at a rate of about $25 \mathrm{~km}$ per three months, and about $18 \mathrm{~km}$ per three months from north to south. Sylvatic rabies covered the entire Croatian territory in the first ten years of its appearance, and then was reported regularly throughout the Croatian territory as epizootics. ${ }^{73,74}$ In certain periods it showed the characteristics of an enzootic..$^{70,73}$

The phylogenetic analysis and genetic characterization of Croatian rabies virus isolates (RABV) were performed on 32 selected rabies-positive brain samples from domestic and wild animals, collected from 2008 to 2010 . The analysis revealed the low genetic diversity of RABV strains currently circulating in Croatia. 18 isolates, mainly originating from Eastern Croatia, clustered with the formerly established Eastern European lineage, and 14 were identical to the West European group. Both groups seem 
to coincide on both sides of the River Sava. A high sequence identity was found in the $\mathrm{N}$ gene of the RABV isolates from neighbouring countries. ${ }^{75}$

\section{DiAgNOSTICS OF RABIES}

According to literature data given in a review article, the first clinical signs may be nonspecific, and lethargy, fever, vomiting, and anorexia are described. In the next few days, signs progress to timidity, cerebral dysfunction, ataxia, weakness, paralysis, seizures, difficulty swallowing, excessive salivation, abnormal behavior, aggression etc. The first laboratory methods were biological trials on rabbits. Soon after that, dogs, mice, rats, guinea pigs and chickens were used. Long-lasting biological trials were replaced by a histological test. In 1903, most of the histopathological signs of rabies were recognized. Adelchi Negri reported the identification of what he believed to be the etiological agent of rabies, the Negri bodies. However, the presence of Negri bodies is variable and not sufficiently sensitive. Different types of cytological test were also used. The rabies virus was cultivated for the first time on a mice kidney tissue culture in $1956 .^{76}$

Today, the fluorescent antibody technique is used, as a rapid and sensitive method for diagnosing rabies in animals and humans. Pathohistological detection of Negri bodies in brain tissue has only historical value. Virus growth in a cell culture from saliva, cerebrospinal fluid or brain tissue suspension of infected animals is used. An objective diagnosis may be obtained by the mentioned, and still the gold standard method - fluorescent antibody technique and the reverse transcription-polymerase chain reaction (RT-PCR) which has been currently recommended by the OIE. ELISA, fluorescent antibody virus neutralization test (FAVN), and rapid fluorescence focus inhibition test (RFFIT) serve for control of immune status after vaccination of humans and animals. ${ }^{77}$

The virus neutralization tests are used for the quantification of specific neutralizing antibodies against rabies virus in serum samples. Serum samples for the control of the immunity of the fox population during ORV campaigns are impossible to obtain, so substances such as muscle extract or thoracic liquid as samples for detection of rabies virus neutralizing antibodies are used for this purpose.

However, the cytotoxic effect limits the use of those substances. A modified fluorescent antibody virus neutralization test $(\mathrm{mFAVN})$ was developed and evaluated for elimination of the cytotoxic effect. In the mFAVN test, inocula were removed after $1 \mathrm{~h}$ and the cytotoxic effect prevented. In the test, no instance of cytotoxic effect was observed in the cells, and muscle extract and thoracic liquid can be used. ${ }^{78}$ Except the mFAVN test, the BioPro ELISA was also evaluated for testing haemolytic thoracic liquids and muscle extracts for the same purpose. The assay was a reliable tool for detection of rabies specific antibodies in the evaluation of oral vaccination of foxes from poor quality samples, as a substitute for virus neutralization tests. ${ }^{79}$

\section{ORAL VACCINATION OF FOXES}

Louis Pasteur developed the first vaccine against rabies. He conducted his experiments using rabbits, and transmitted the causative agent from rabbit to rabbit by intracerebral inoculations until he obtained a stable preparation. In order to attenuate the infective agent, he desiccated the spinal cords of infected animals until the preparation became almost nonvirulent. With the weakened carrier, he successfully vaccinated dogs against rabies. ${ }^{80}$ During the 1950 s and 1960 s a virus strain, Flury LEP, was used for mass vaccination of dogs. The vaccine was shown to be safe when inoculated intramuscularly into dogs. ${ }^{42}$ Live attenuated and inactivated vaccines against rabies were used in the preventive vaccination of animals. Flury LEP (Low Egg Passage), however, occasionally caused rabies in young pups, cats and cattle. It was replaced with Flury HEP (High Egg Passage), which was safe. Vaccines prepared from the SAD (Street Alabama Dufferin) strain were also used. In addition, inactivated and subunit vaccines were produced. A recombinant vaccine, carrying the glycoprotein $(\mathrm{G})$ gene, was indicated as a safe and efficacious vaccine. Oral vaccination of foxes was indicated as a possible tool for elimination of sylvatic rabies. ${ }^{81,82,83}$

Despite the implementation of preventive dog vaccination, rabies has become endemic in Croatia. After test campaigns conducted in some districts of Istarska County, Primorsko-goranska County and Karlovac County, the first oral immunization of foxes against rabies was performed in the Zagreb County and the Zagreb Municipality in 1998. Baits with Fuchsoral vaccine were set out on hunting areas and Medvednica National Reserve. The bones of fox carcasses were tested for tetracycline content. It was proved that $58.9 \%$ of foxes ate the bait. Neutralizing antibodies to rabies virus were detected in $46.5 \%$ of tested foxes. ${ }^{28}$ Unfortunately, all activities regarding oral immunization of foxes stopped until 2011.

In the spring of 2011, Croatia started a program of oral vaccination of foxes in the northern part of the country, with the support of the EU. In the next few years the program was extended to the entire country. Oral rabies vaccination (ORV) campaigns have been conducted twice a year. The Lysvulpen vaccine, containing the SAD Bern strain, was used. Twenty-five baits were distributed per square $\mathrm{km}$, with circa $80 \mathrm{~m}$ between each bait. The baits were dropped automatically using an aircraft. The number of positive cases rapidly decreased, and in 2013, only 35 positive cases were detected, of which 33 involved foxes, one dog, and one horse. In a short period, after only 32 months, rabies was eliminated. The last case was recorded in February 2014. The results showed that a thoroughly performed oral rabies vaccination program is extremely useful and efficacious (Fig 1). ${ }^{7}$ The analysis of the efficiency of the oral vaccination campaign in the territory of Croatia in the period from 2010 to 2017 showed that, prior to the commencement of the oral vaccination campaign, $15.8 \%$ positive specimens were revealed from all foxes 
tested for rabies, and after just one oral immunization campaign, this percentage decreased to $9 \%$ positive individuals. ${ }^{84}$

The trend of decreasing of the number of positive animals is clearly visible from the graph showing the period from three years before the start of the ORV, until today, when we are recording the sixth year without a single rabid animal in Croatia (Figure 1).

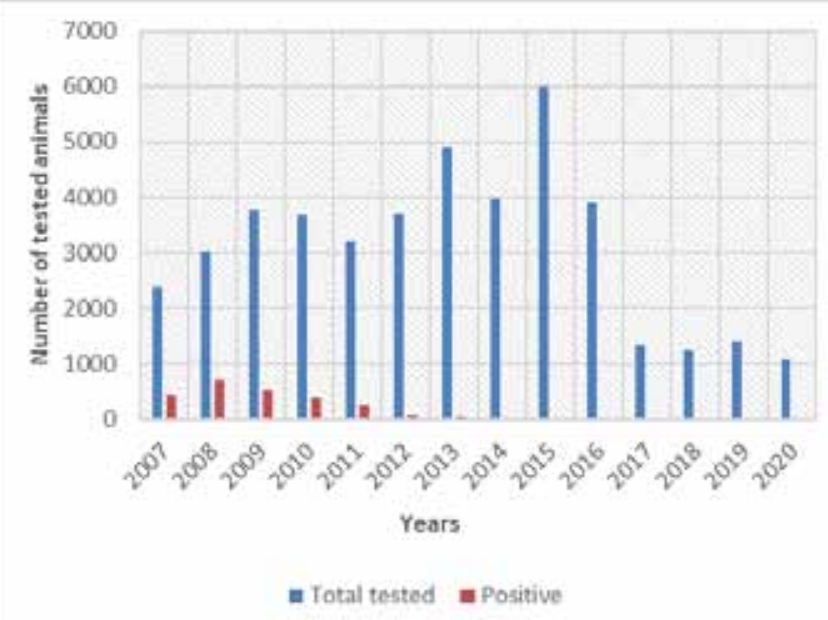

Figure 1. Number of tested and positive animals using the fluorescent antibody technique in the National Reference Laboratory for Rabies, Croatian Veterinary Institute in Zagreb, from 2007 to 2020.

\section{LYSSAVIRUSES IN BATS}

Bats have been identified as the most common reservoir for all Lyssaviruses, except Mokola and Ikoma viruses. Many genetically and antigenically distinct variants of rabies viruses have been detected in insectivorous bats, in vampire bats, as well as in herbivorous bats. They are often transmitted to domestic animals and humans. ${ }^{1}$ As reported by Karlović, rabies is transmitted by bites, saliva, milk, prenatally, and by aerosol and droplets of infected bats. Infected bats demostrate characteristic symptoms and die, or do not show any symptoms for a long period, but become carriers and excrete the virus. Rabies virus in bats is most widespread in Central and South America, where it is transmitted to cattle, horses and people by vampire bats. It was first established in Brazil in 1916, and the first proven case in humans transmitted by an insectivorous bat was found in the USA in $1953.85,86$ A review of bat transmitted rabies was undertaken on the basis of literature data. The case of a woman in Australia who died after a bat bite was reported. A virus closely related to some members of the Lyssavirus genus was isolated from a bat (Pteropus alecto) in which encephalitis had been detected. ${ }^{87}$ Some epizootiological characteristics of rabies transmitted by vampire bats in Brazil, and insectivorous bats in Europe were briefly mentioned as an example of the spread of the rabies virus. ${ }^{57}$

In 1985, bat rabies surveillance programs started in some western European countries. Low seroprevalence was recorded (1-9.1\%). More than 1000 bat species are known, and they represent the second largest group of mammals on the planet. Bats exist in abundance in Croatia, with 35 insectivorous species from three families. An initial investigation of zoonotic diseases in bats was performed for military purposes in 1968. At that time, in total 470 bats from Croatian caves were tested in Prague, using immunofluorescence on inoculated mice brains. All tested samples were found negative for rabies virus. ${ }^{88}$

A limited study of bat rabies in Croatia undertaken in 1986 showed that all 30 tested bats were found negative for rabies by a fluorescence antibody test. The study was stopped because of the Homeland War. However, the Croatian Veterinary Institute, in cooperation with the Croatian Natural History Museum, began analyzing the available bat samples and testing them for rabies in $2008 .^{89}$ This passive surveillance was poor and negligible with only 124 bats submitted for rabies testing from 2010 to 2017 . Since the data on bat rabies in Croatia were scarce, in 2016 a national project, financed by Croatian Science Foundation, was launched. The objective of the project was to establish the presence of rabies virus and other zoonotic viruses in bats in Croatia. During the active surveillance, between 2016 and 2017, 455 bats were caught. Results searching the rabies virus were obtained for 350 bats. In total, 20 serum samples showed a detectable level of neutralizing antibodies against European bat lyssavirus-1, using a modified fluorescent antibody virus neutralization assay..$^{90,91}$ Rabies in wildlife will never be completely eradicated. It is evident that the virus is constantly present in bats, so continuing education and awareness about the possibility of infection from this protected species is necessary. And this is not only due to rabies, but also due to other infections that possibly threaten from bats because of the expanding urbanization that promote more frequent contact between human and wildlife habitats.

\section{CONCLUSION}

Rabies elimination and control is a strategic goal and top priority in the EU. Over the past two centuries, many scientific and professional papers on the incidence of rabies in domestic and wild animals have been published in Croatia. Due to the implementation of the fox oral vaccination program, the last case of a rabid fox was recorded in Croatia in 2014, and Croatia is expected to be officially declared free of classical terrestrial rabies by 2020 . 


\section{LITERATURE:}

1. World Health Organization. Expert Consultation on Rabies. WHO Technical Reports Service N¹012, Third report 2018.

2. World Rabies Day 2020. World Health Organization (2020). Available: https://www.who.int/news-room/detail/28-09-2020-worldrabies-day-2020 access 11.10.2020.

3. European Commission. Directorate-General (DG) for health and food safety, Overview report - rabies eradication in the EU. 2017. http://doi: $10.2772 / 58274$

4. Palmović D. 50 godina rada Pasterovog zavoda u Zagrebu. Lij vjesn. 1970;92:789-95. (in Croatian)

5. Vodopija E, Bobinac E. Pola stoljeća antirabične službe u Hrvatskoj. Lij vjesn. 1970;92:797-8. (in Croatian)

6. Mutinelli F, Stankov S, Hristovski M, Seimenis A, Theoharakou H, Vodopija I. Rabies in Italy, Yugoslavia, Croatia, Bosnia, Slovenia, Macedonia, Albania and Greece. In: King, AA, Fooks AR, Aubert M, Wandeler AI. eds. Historical perspective of rabies in Europe and the Mediterranean basin. A testament to rabies by Dr Arthur A. King. OIE (World Organisation for Animal Health). Paris, France: 2004. pp 93-118. http://www.oie.int

7. Bedeković T, Lohman Janković I, Šimić I, Krešić N, Lojkić I, Sučec I, et al. Control and elimination of rabies in Croatia. PLoS ONE 2018;13(9): e0204115. https://doi.org/10.1371/journal. pone. 0204115

8. Lojkić I, Šimić I, Krešić N, Lohman Janković I, Bedeković T. U sjeni pandemije s COVID-19: Ususret proglašenju Hrvatske slobodnom od bjesnoće. Vet stanica. 2020;51:417-23. (in Croatian) 9. Walker PJ, Blasdell KR, Calisher CH, Dietzgen RG, Kondo H, Kurath G, et al. ICTV Report Consortium. ICTV Virus Taxonomy Profile: Rhabdoviridae. J Gen Virol. 2018;99:447-8. https://doi. org/10.1099/jgv.0.001020.

10. Marston DA, Horton DL, Ngeleja C, Hampson K, McElhinney LM, Banyard AC, et al. Ikoma Lyssavirus, highly divergent novel Lyssavirus in an African Civet. Emerg Infect Dis. 2012;18:664-7. https:// dx.doi.org/10.3201/eid1804.111553

11. Dato VM, Campagnolo ER, Long J, Rupprecht CE. A systematic review of human bat rabies virus variant cases: evaluating unprotected physical contact with claws and teeth in support of accurate risk assessments. PLoS ONE 2016;11(7): e0159443. https://doi. org/10.1371/journal.pone. 0159443

12. Fooks A, Cliquet F, Finke S, Freulings C, Hemachudha T, Manis R, et al. Rabies. Nat Rev Dis Primers. 2017;3:17091. https://doi. org/10.1038/nrdp.2017.91

13. Udow SJ, Marrie RA, Jackson AC. Clinical features of dog- and bat-acquired rabies in humans. Clin Infect Dis (CID) 2013;57:68996. https://doi.org/10.1093/cid/cit372

14. Coleman PG, Dye C. Immunization coverage required to prevent outbreaks of dog rabies. Vaccine. 1996;14:185-6. https://doi. org/10.1016/0264-410X(95)00197-9

15. World Health Organisation (WHO). Expert consultation on rabies. First report. World Health Organ. Tech. Rep. Ser. 931;2005:1-88.
16. Karlović M, Lojkić M, Čač Ž. Deset godina silvatične bjesnoće u Hrvatskoj. Vet stanica. 1987;18:139-46. (in Croatian) 17. Cvetnić, S. Virusne bolesti životinja. Školska knjiga, Zagreb, 1997;201-209. (in Croatian)

18. Baer GM, Abelseth MK, Debbie JG. Oral vaccination of foxes against rabies. Am J Epidemiol. 1971;93:487-90.

19. Freuling CM, Hampson K, Selhorst T, Schröder R, Meslin FX, Mettenleiter TC, et al. The elimination of fox rabies from Europe: determinants of success and lessons for the future. Phil Trans R Soc B. 2013;368: 20120142. http://dx.doi.org/10.1098/rstb.2012.0142 20. Steck F, Wandeler AI, Bichsel P, Capt S, Schneider LG. Oral immunisation of foxes against rabies. A field study. Zbl Vet Med B. 1982;29:372-96. https://doi.org/10.1111/j.1439-0450.1982.tb01237.x 21. Müller T, Freuling CM, Wysocki P, Roumiantzeff M, Freney J, Mettenleitr TC, Vos A. Terrestrial rabies control in the European Union: Historical achievements and challenges ahead. Vet J. 2015;203:10-7. https://doi.org/10.1016/j.tvjl.2014.10.026

22. Karlović M, Sudnik I. Istine i zablude o bjesnoći u Hrvatskoj prema zapisima u 18. i 19. stoljeću. Vet stanica. 1989;20:361-7. (in Croatian) 23. Karlović M, Lojkić M, Milinčević M. Prikaz širenja silvatične bjesnoće u Hrvatskoj (1977. -1981). Praxis vet. 1981;29:417-22. (in Croatian)

24. Frari J. Riflessioni teorico-mediche sopra una grave malattia. Ancona: 1783. (in Italian)

25. Castelli L. Uvicbanja za poznati bist pasaa i za podati parve potribite pomochi ujidenim. Zara: 1822. (in Croatian)

26. Lalić J. Podučanje u upotrebljavanju sredstva za izlečenje (vračenje) besnoće (stoke) kod ljudi i živine. Zagreb: 1842. (in Croatian)

27. Lalić J. Način vračtva suproti steklini, iliti ugrizu besnih pasah pri čoveku i blagu kak’ također suproti kačnom ugrizu. Beč: 1844; 26 p. (in Croatian)

28. Čač Ž. Uspješnost oralnog cijepljenja lisica protiv bjesnoće provjerom njihova imunosnog stanja. Disertacija. Zagreb: Veterinarski fakultet, Sveučilište u Zagrebu 2003. 156 p. (in Croatian)

29. Kišpatić M. Životinje. Društvo Sv. Jeronima. Zagreb: 1872. (in Croatian)

30. Sabolić M. Stotinu godina bjesnoće na varaždinskom području (1900.-2000.) Zagreb: Medicinska naklada; 2002. 73 p. (in Croatian) 31. Karlović M. Uvođenje poreza na pse i psećih markica u drugoj polovici XIX. stoljeća kao prilog preventivi i suzbijanju bjesnoće u Zagrebu. Vet arhiv. 1985;55:231-6. (in Croatian)

32. Karlović M, Mirnik M. 125. obljetnica uvođenja psećih markica u Hrvatskoj. Vet stanica. 1994;25:285-95. (in Croatian)

33. Sabolić M. Propisi o dostavi materijala Bakteriološkom zavodu u Križevcima radi pretrage na bjesnoću na području Kraljevine Hrvatske i Slavonije. Vet stanica. 2002;33:303-6. (in Croatian)

34. Sabolić M. Pravilnik o držanju pasa na području Savske Banovine. Vet stanica. 1999;30:107-10. (in Croatian)

35. Kodrnja E. Problem bjesnoće u Jugoslaviji i potreba dopune veterinarsko-redarstvenih mjera antirabičnim cijepljenjima. Vet glasnik. 1939;19:51-74. (in Croatian) 
36. Kodrnja E. Canis rabiosus. Jugoslavenski veterinarski glasnik 1935;15:100-101. (in Croatian)

37. Kodrnja E. Bjesnoća u životinja u Evropi 1937. i 1964. godine. Vet arhiv. 1968;38:152-4. (in Croatian)

38. Ježić J, Kodrnja E. Prva terenska preventivna cijepljenja protiv bjesnoće u Jugoslaviji. Vet arhiv. 1937;7:1-48. (in Croatian)

39. Kodrnja E. Zaštitna ciepljenja pasa protiv bjesnoće u Slavoniji. Vet arhiv. 1944;14:317-50. (in Croatian)

40. Kodrnja E. Deset godina suzbijanja bjesnoće. Vet arhiv.

1959;29:132-44. (in Croatian)

41. Kodrnja E. Kretanje i suzbijanje bjesnoće u nas od 1946. do 1969.

Vet arhiv. 1970;40:303-13. (in Croatian)

42. Kodrnja E. Flury LEP vakcina bjesnoće. Vetserum. 1969;17:89-97.

(in Croatian)

43. Cvetnić S. Bjesnoća. Rabies.Lyssa-Hydrophobia. Zagreb: JUMENA

- Jugoslavenska medicinska naklada; 1989. 201 p. (in Croatian)

44. Borčić B. Rabies se ponovo širi Hrvatskom. Lij vjesnik.

1978;100:563-4. (in Croatian)

45. Palmović D. Bjesnoća u čovjeka s posebnim osvrtom na postekspozicijsku profilaksu. Praxis med. 1981;12:65-72. (in Croatian) 46. Ljubičić M, Baklaić Ž, Svjetličić M, Vodopija I. Zaštita ljudi od bjesnoće nekad i danas. Vet stanica. 1987;18:157-64. (in Croatian) 47. Ljubičić M, Baklaić Ž, Svjetličić M, Gotovac P, Smerdel S, Lojkić M, Vodopija I. Bjesnoća - trajno nazočni problem. Vet stanica. 1990;21:69-74. (in Croatian)

48. Lisić M, Himbele J, Beus I, Marton E, Baršić B, Poljaković Z. The clinical picture of rabies in a child. Neurol Croat. 1991;40:307-18.

49. Lojkić I, Galić M, Čač Ž, Jelić I, Bedeković T, Lojkić M, Cvetnić

$\check{Z}$. Bites of a rabid wolf in 67-old man in north-eastern part of Croatia.

Rabies Bulletin. 2009;33:5-7.

50. Karlović M, Lojkić M. O širenju silvatične bjesnoće u Evropi (1945. - 1981.). Praxis vet. 1981;29:411-15. (in Croatian)

51. Karlović M, Lojkić M. Sadašnje stanje bjesnoće u Jugoslaviji s posebnim osvrtom na Hrvatsku. Vet arhiv Suppl. 1985;55:S16-S19. (in Croatian)

52. Karlović M, Lojkić M, Čač Ž. Deset godina silvatične bjesnoće u Hrvatskoj. Vet stanica. 1987;18:139-46. (in Croatian)

53. Cvetnić S. Bjesnoća. Rabies. Vet stanica. 1987;15:137-8. (in Croatian) 54. Petrović M, Panjević, Pauković Č, Železnik Z. Besnilo u Jugoslaviji - epizootiološka sitauacija i suzbijanje. Vet glasnik. 1980;34:621-32. (in Serbian)

55. Čač Ž. Bjesnoća u mačaka u Hrvatskoj od 1977. do 1987. Vet stanica. 1987;18:147-9.

56. Peroković T. Prvi susret s bjesnoćom. Vet stanica. 1990;21:239-40. (in Croatian)

57. Pauković Č. Bjesnoća divljih životinja. Izvještaj sa seminara Svjetske zdravstvene organizacije u Ženevi (2.-5. srpnja 1990.). Vet stanica. 1991;22:111-7. (in Croatian)

58. Lojkić I, Bedeković T, Čač Ž, Lemo N, Cvetnić Ž. Clinical rabies in cattle imported into Croatia. Vet Rec. 2013;172:22-3. http://dx.doi. org/10.1136/vr.e8619
59. Čač Ž, Lojkić M, Vinković B. Proširenost bjesnoće u Hrvatskoj od 1986. do 1990. godine. Praxis vet. 1992;40:45-56. (in Croatian) 60. Čač Ž, Brstilo M, Rajić A. Proširenost i nadzor bjesnoće u Hrvatskoj od 1986. do 1992. godine. Vet stanica. 1994;25:159-67. (in Croatian) 61. Čač Ž. Silvatična bjesnoća u Hrvatskoj: pojava, širenje i sadašnje stanje. Infekt glasnik. 1996;16:1-4. (in Croatian)

62. Čač Ž, Lojkić M. Dva desetljeća suživota sa silvatičkom bjesnoćom. 3. znanstveni skup iz DDD-a s međunarodnim sudjelovanjem

"Zdravo očuvati zdravim" (Zadar,7-9. svibnja 1998) Priopćenja. Zadar, 1998;309-16. (in Croatian)

63. Čač Ž, Lojkić M, Roić B, Jemeršić L. Bjesnoća kod divljači u Republici Hrvatskoj od 1977. do 2001. godine. Veterinarski dani (Rovinj, 2002). Zbornik sažetaka. Zagreb 33-34. Zagreb p.33-34. (in Croatian)

64. Milinčević M, Periškić M, Kovač Z. Bjesnoća u Slavoniji i Baranji od 1981. do 1990. godine. Vet stanica. 1992;23;149-53. (in Croatian) 65. Periškić M, Milinčević M, Kovač Z. Bjesnoća u Slavoniji i Baranji od 1991. do 1995. godine. Vet stanica. 1996;27:131-5. (in Croatian) 66. Čač Ž. Bjesnoća pasa u Republici Hrvatskoj tijekom epidemijskog razdoblja silvatične bjesnoće (1977.-2002.) Praxis vet. 2003;51:115-23. (in Croatian)

67. Šoštarić B, Čač Ž, Lojkić I, Mihaljević Ž, Dežđek D, Novosad D. Epizootija bjesnoće u ovaca - prikaz slučaja. Vet stanica. 2010;41:14561. (in Croatian)

68. Sabolić M. Raširenost i nadzor bjesnoće na području Veterinarske stanice Varaždin u razdoblju od 1985. do 1995. godine. Vet stanica. 1996;27:267-73. (in Croatian)

69. Sabolić M. Redukcija populacije lisica, značajan je čimbenik u suzbijanju i nadzoru bjesnoće. Vet stanica. 2004;35:77-83. (in Croatian) 70. Sabolić M. Neki epizootiološki aspekti bjesnoće u životinja na varaždinskom području. Vet stanica. 2006;37:89-94. (in Croatian) 71. Sabolić M. Bjesnoća i javno zdravstvo u Županiji Varaždinskoj. Vet stanica. 2005;36:151-8. (in Croatian)

72. Slavica A, Cvetnić Ž, Čač Ž, Konjević D, Sindičić M, Janicki Z, Dežđek D, Severin K. Silvatic rabies in urban Croatian environment. $10^{\text {th }}$ Croatian Biological Congress with International Participation, Osijek 2010. Proceedings, Zagreb 2010 p. 110-1.

73. Slavica A, Severin K, Čač Ž, Cvetnić Ž, Lojkić M, Dežđek D, Konjević D, Pavlak M, Budinščak Z. Model širenja silvatične bjesnoće na teritoriju Republike Hrvatske tijekom perioda od trideset godina. Vet stanica. 2010;41;199-210. (in Croatian)

74. Alegro A. Svaka lisica je bijesna dok se to ne opovrgne. Lov vjesnik. 1997;1-2/97;17-8. (in Croatian)

75. Lojkić I, Čač Ž, Bedeković T, Lemo N, Brstilo M, Müller T, Freuling CM. Diversity of currently circulating rabies virus strains in Croatia. Berl Münch Tierärztl Wochenschr. 2012;125:224-54. PMID: 22712423 DOI 10.2376/0005-9366-125-24

76. Karlović M, Lojkić M. Dijagnostika bjesnoće od Pasteura do danas. Vet stanica. 1987;18:151-6. (in Croatian)

77. Čač Ž, Lojkić I, Bedeković T, Lojkić M. Laboratorijska dijagnostika bjesnoće. Vet stanica. 2009;40:361-72. (in Croatian) 
78. Bedeković T, Lemo N, Lojkić I, Ž, Jungić A, Cvetnić Ž, Čač Ž, Hostnik P. Modification of the fluorescent antibody virus neutralisation test--elimination of the cytotoxic effect for the detection of rabies virus neutralising antibodies. J Virol Methods. 2013;189:204-8. DOI: https://doi.org/10.1016/j.jviromet.2013.01.022

79. Bedeković T, Šimić I, Krešić N, Lojkić I, Mihaljević Ž, Sučec I, Lohman Janković I Hostnik P. Evaluation of ELISA for the detection of rabies virus antibodies from the thoracic liquid and muscle extract samples in the monitoring of fox oral vaccination campaigns. BMC Vet Res. 2016;12:76 DOI: https://doi.org/10.1186/s12917-016-0701-0 80. Cvetnić S. Louis Pasteur i veterinarska medicina. Vet stanica. 1996;27:97-102 (in Croatian)

81. Madić J. Vakcine i vakcinacija životinja protiv bjesnoće. Vet stanica. 1987;18:165-71. (in Croatian)

82. Madić J, Brstilo M. U povodu oralne vakcinacije lisica protiv bjesnoće u Hrvatskoj. Vet stanica. 1995;26:1-2. (in Croatian) 83. Šeparović S, Lamer D. U Zagrebu održana WHO konferencija (tema - Kontrola bjesnoće i oralno cijepljenje lisica). Hrv vet vjesnik. 1996;6:20-1. (in Croatian)

84. Kranjčec $S$, Slavica A. Procjena uspješnosti oralne vakcinacije lisica $s$ obzirom na suzbijanje bjesnoće na teritoriju Republike Hrvatske. Veterinar 2019;57:15-24. (in Croatian)
85. Karlović M. Šišmiš kao potencijalni rezervoar i širitelj bjesnoće. Vet stanica. 1988;19:257-8. (in Croatian)

86. Karlović M. Šišmiš kao izvor bjesnoće: stvarnost ili pretpostavka. Praxis vet. 1999;47:109-23. (in Croatian)

87. Brudnjak Z. Novi virus šišmiša u Australiji. Vet stanica.

1997;28:147-8. (in Croatian)

88. Heneberg Đ, Bakić J, Heneberg N, Nikolić B, Agoli B, Hronovsky $\mathrm{V}$, Dusbabek F, et al. Ekološko-medicinska ispitivanja pećina dalmatinskog krša. Zb Vojnomed Akad. 1968;43-6. (in Croatian)

89. Pavlinić I, Čač Ž, Lojkić I, Đaković M, Bedeković T, Lojkić M. Šišmiši biološki rezervoari i potencijalni prijenosnici lyssavirusa. Vet stanica. 2009;40:297-304 (in Croatian)

90. Šimić I, Krešić N, Lojkić I, Bedeković T. Bjesnoća u zvijeri i šišmiša u Republici Hrvatskoj. Vet stanica. 2017;48:145-51. (in Croatian) 91. Šimić I, Lojkić I, Krešić N, Cliquet F, Picard-Meyer E, Wasniewski $\mathrm{M}$, Čukušić A, Zrnčić V, Bedeković T. Molecular and serological survey of lyssaviruses in Croatian bat populations. BMC Vet Res. 2018;14;274. https://doi.org/10.1186/s12917-018-1592-z 
